\title{
Review of Mark D. White's The manipulation of choice: ethics and libertarian paternalism. New York: Palgrave Macmillan, 2013, 208 pp.
}

\author{
AlEX ABBANDONATO \\ New Brunswick Human Rights Commission
}

Mark White's book is a critique of the theory of libertarian paternalism popularized by Cass Sunstein and Richard Thaler's Nudge: improving decisions about health, wealth and happiness (2009). Sunstein and Thaler propose policymakers improve the well being of citizens by 'nudging' us to make better choices in our day-to-day lives. Take the American example of employee enrolment in 401 (k) pension plan accounts. Sunstein and Thaler argue that changing the default option to automatic enrolment would be in the interests of the majority of employees who procrastinate about investing in their retirement, while still allowing them to opt out if they so choose. Such policies are considered libertarian because they do not limit people's choices, and yet also paternalistic, because choices are framed in such a way that the choice maker will be nudged to make the decision the 'choice architect' believes is the right one.

White argues against libertarian paternalism in both theory (chapters 1-3) and practice (chapters 4-6). The first part critically analyses the theories that underpin libertarian paternalism: traditional choice models, behavioural economics, and law and economics. White's original contribution here is an analysis of the importance of principles, judgement and the will in coordinating human interests. The second part focuses on libertarian paternalism in practice with chapters making a case against it from an informational and ethical perspective and a chapter analysing the distinctions in practice between private and government nudges.

In the opening chapters of the book, White explores whether traditional economic models properly account for how individuals make choices, since it is on these models that the choice architecture of nudges is based. The first problem White identifies is that the traditional assumptions of preferences, constraints, and trade-offs are overly simplistic: they do not account for the variety of interacting 
aspects that make up human interests. There are three features that traditional choice models neglect: principles, judgement, and the will.

First, traditional models overlook moral principles, which can place binding constraints on human action. The principles we endorse become part of our character and identity, producing both important and consistent influences on our choices. White explains that principles are not easily substituted for preferences which make them difficult to fit into the traditional models. Principles, for instance, have the "property of limiting our discretion to make different trade offs among preferences when circumstances change" (p. 9). White gives the example of a couple who refuse to buy a car made by a particular company because they disapprove of its business practices, regardless of how low a price they are offered.

Traditional models suppose that the economic actor is concerned only with utility maximization, i.e., with achieving the greatest possible satisfaction of her preference ordering given her resource constraints. White provides examples to illustrate how even the simplest consumer choices are more complex than this recognises because people routinely face conflict between their preferences and principles. This brings out the crucial role of judgement in the human decision-making process. As White puts it, "we must utilize our judgement to balance conflicting principles and arrive at an answer that maintains our moral character" (p. 14).

Finally, whether we act on our judgement or not requires the use of willpower. An individual's strength of will determines if they are able to follow through on what they have decided is best. As White argues:

Willpower is the necessary bridge between making a decision and acting on it [...] But very few economists recognize the existence of a will that either carries out the decisions that our judgement tells us is best, or leads to another action altogether (p. 18).

The second problem White identifies with traditional models is that economists view preference satisfaction as equivalent to 'well-being'. This is problematic because many of our preferences are not consistent with improving our well being, defined in the general sense of a life that is going well. (Sunstein and Thaler themselves define well-being more objectively as health and wealth.) People have a wide range of motivations for their choices, such as: other-regarding concerns, self destructive desires, moral principles, and general social ideals, which do 
not always further their well-being in this general sense. In solely focusing on the satisfaction of preferences economists ignore how individuals make decisions.

In the next chapter, White extends his critique to behavioural economics, which elaborates on the assumptions of traditional choice models. For instance, Amos Tversky and Daniel Kahneman added cognitive biases and heuristics to economic models of choice. Unfortunately, while behavioural economics expands the scope of analysis-in particular accepting that people can choose badly-it does not address White's critique of traditional models. It does not recognize the role of principles, judgment, and the will as determining factors. White illustrates this point through the example of Patrick, an overweight man who eats a muffin every Sunday morning at a cafe. From the perspective of the 'choice architect', Patrick is making an irrational choice because he is contributing to his poor health. But Patrick could have many interests which eating the muffin fits well within, as White explains (perhaps his now deceased grandfather took him to the cafe every Sunday, and he eats a muffin in remembrance of the lessons and experiences they shared). Yet all the behavioural economist perceives is an overweight man eating a muffin. This introduces White's two major problems with libertarian paternalism. First, there is no way for an outside observer to know what a person's interests are; and second, even if they were known it would still be illegitimate for a policy maker to try and nudge her choice.

White begins his direct challenge to libertarian paternalism in the fourth chapter by reaffirming his original claim-that the sum of human interests is far more complex than these models allow. This poses an informational problem for libertarian paternalism: it claims to do what is in the best interests of the citizenry, but there is no way for an outside observer to know a person's best interests or what motivates their choices unless that is made explicit. The only glimpse we get of people's different interests is from their choices, which libertarian paternalists desire to alter. While claiming to do what is in our best interest, policymakers actually nudge people into acting in what they believe people's interests ought to be, substituting their values for our own.

White refers to the work of a number of influential philosophers. He quotes Gerald Dworkin's definition of paternalism: "a usurpation of decision-making, either by preventing people from doing what they have 
decided or by interfering with the way in which they arrive at their decisions". White also refers to John Stuart Mill's 'harm principle' as a guide to the limits of legitimate interference with individual action, and to Immanuel Kant's view that deception and coercion are the two prominent ways that an individual's autonomy can be compromised. White's ethical case against libertarian paternalism derives from the insights of these philosophers, focused into two critiques.

His first critique, which he shares with Riccardo Rebonato (author of Taking liberties: a critical examination of libertarian paternalism, 2012), is that nudges are not value free, and that value substitution as a governing philosophy violates people's autonomy and the respect that is due by projecting one person's interests onto another. It violates a person's autonomy by directly interfering, albeit 'softly', in their choices.

White's second critique is that libertarian paternalism manipulates the cognitive biases and heuristics that behavioural economists identified. Here White makes a distinction between soft paternalism and hard paternalism. Hard paternalism, such as taxes and legal prohibitions, use state power to directly alter our behaviour; soft paternalism, such as libertarian paternalist nudges, wields power secretly, outside our awareness. Hard paternalism is immediately evident because it affects the constraints on our decision making. In contrast, libertarian paternalism manipulates the cognitive biases and heuristics that affect our decision-making process itself, and thus generally goes unnoticed.

This critique of nudges, and behavioural economics in general, in terms of secretive manipulation is a strong one, since it strikes at the root of the idea of nudges as a solution to poor choice making. It is shared by other sceptics of libertarian paternalism, such as Gilles Saint-Paul in his book The tyranny of utility: behavioral social science and the rise of paternalism (2011). White develops the point by connecting it with the learning process. Nudges exasperate the bad choice habits they claim to fix by latching onto the very same cognitive biases and heuristics that produce our objectionable choices to begin with. It is through the negative consequences of our choices that we learn how to make better ones. If choices are manipulated, this learning process is weakened or removed. Predetermined government correction to possible mistakes disrupts the environmental feedback that generates learning, and does not help agents improve their choice making in the future. 
White goes on to deal with the ethical distinction between business nudges to manipulate customers and government nudges to manipulate citizens. His reasoning is that it comes down to purpose and respect. Businesses' interests are transparent and single minded-to maximize profit-and so, "they do not presume to make choices for their customers in their own interests" (p. 109). As customers we are aware of our relationship to businesses and can respond appropriately. Moreover, businesses exercise no coercive power over customers because we are always free to exit the relationship (p. 107). Yet, Dworkin's definition of paternalism, which White endorsed, would seem to cover any power, private or governmental, "interfering with the way in which [people] arrive at their decisions". This creates an inconsistency in the way paternalism is defined in the book.

Thaler and Sunstein argue that what separates libertarian paternalism from traditional ('hard') paternalism is precisely its noncoerciveness, since 'choice architects' do not prohibit choices but rather frame them in specific ways. An important counter argument to White is that, in a great many cases, a choice about framing does have to be made one way or another. The ethical question, Sunstein and Thaler argue, is not whether to become a 'choice architect', but how one should exercise that power responsibly (Thaler and Sunstein 2003, 175). Shopkeepers, school teachers, parents, politicians, and many others all face this ethical challenge. White deals with this through a framework that distinguishes between those close to us, such as friends and family, who may legitimately attempt to influence our choices because of their greater knowledge of our interests and closer connection to the consequences of our choices, in contrast to government agencies which cannot know us as individuals and which therefore end up manipulating us in ways that disrespect our interests. Thus,

If we understand respect to be the attitude required of everybody based on our shared humanity, and care to be an appropriate attitude only for people who are close to each other and have some idea of each other's interests, then we can see the problem with paternalism (p. 117).

While I can go along with White's distinction, it could do with further explanation of how it fits with the philosophical analysis of paternalism that he cited and endorsed earlier in the book (i.e., Dworkin, Mill, and Kant). The chapter goes on to explore possible exceptions to the 
general rule: acceptable government nudges (e.g., food labelling) and unacceptable business nudges (e.g., default retirement plan enrolment). It ends by returning to previous points on value substitution and distortions in learning feedback, which works well at cementing earlier points but left this reader feeling that the new concepts White introduced could have been more thoroughly explained.

The work is a solid, compelling read for anyone interested in a concise but comprehensive account of the case against libertarian paternalism and its theoretical foundations. The book is well organized: each chapter focuses on a distinct issue and this complemented by overlapping discussion of earlier points throughout, emphasising the interconnectedness of libertarian paternalism's many nuances. An excellent feature of the book is White's use of many relatable and entertaining examples which can connect with any reader, whether or not they come from an economics background. The book stands out from other recent critiques of libertarian paternalism (such as I have cited). It retains the strongest points of earlier critiques while also offering additional contributions, as noted in this review. In the course of battling libertarian paternalism and its underlying theories, White simultaneously builds a positive case for individual freedom in defence of more traditional, non-paternalistic paradigms of libertarian philosophy and economics.

\section{REFERENCES}

Rebonato, Riccardo. 2012. Taking liberties: a critical examination of libertarian paternalism. New York: Palgrave Macmillan.

Saint-Paul, Gilles. 2011. The tyranny of utility: behavioural social science and the rise of paternalism. Princeton (NJ): Princeton University Press.

Thaler, Richard H., and Cass Sunstein. 2003. Libertarian paternalism. American Economic Review, 92 (2): 175-179.

Thaler, Richard H., and Cass Sunstein. 2009. Nudge: improving decisions about health, wealth and happiness. London: Penguin.

Alex Abbandonato earned his MA in international political economy from Newcastle University (UK) in 2012. He is currently a human rights officer in New Brunswick, Canada.

Contact e-mail: <a.abbandonato@outlook.com> 